\title{
Between Old and New: Flanerie at the Limits of Modernity in Orhan Pamuk's A Strangeness in My Mind
}

\author{
Rupayan Mukherjee \\ Ph.D Scholar \\ University of North Bengal \\ West Bengal, India \\ rupss.joy@gmail.com
}

\begin{abstract}
The present chapter locates the flaneur in the tension of tradition and modernity in the seminal novel A Strangeness in Mind by the Nobel laureate Orhan Pamuk. The flaneur is a predominant archetype in the literary and cultural imaginary of Modernism. As such, rather unsurprisingly, the flaneur plays a significant role in the subsequent explorations of the salient traits, juxtapositions and the nuances that constitute the event of modernity. The evaluation of modernity often involves an inevitable exploration of the performance and essence (often inseparable) of flanerie. The present paper proposes to explore this interspersed relationship between flanerie and modernity through a strategic reading of the novel. The chapter will substantiate Mevlut, the boza seller protagonist in the novel, as a flaneur who is the embodiment of Turkish modernity. The chapter will argue that the perpetual status of Mevlut as a hyphenated self who is characterised by the interplay of apprehension-appreciation and is unconditionally hospitable to the contingence of the temporal-spatial substantiate him as the flaneur in the novel. In doing so, the chapter will also identify the essence of Turkish modernity and will locate it in departure from the unanimous notional conjecture of modernity as progress.
\end{abstract}


Keywords: Modernity, Flaneur, Material-lived, Dasein, Liminal.

The form of a city

Changes faster, alas! Than the human heart.

\section{Charles Baudelaire, "The Swan".}

Modernity apparently trails with a presumed aura of newness; to be modern is to suggest, almost pre-conditionally, that there is a difference or departure from that which is the archaic, the stable, the established - that which one can half-convincingly categorise as tradition. Hence, tradition and modernity are often interrelated yet opposed considerations/ conditions where the suggestive material trace of the one assumes the absence of the other. To be modern is to exist in a state of autonomy where the eclipse of history does not haunt the solstice of the present. Modernity is a valorization of the 'now' of present against the archaic time of history. Jurgen Habermas, one of the celebrated thinkers of the Modern age who explores the nuances of the condition of modernity, observes

"Individual epochs lose their distinct forces. Historical memory is replaced by the heroic affinity of the present with the extremes of history - a sense of time wherein decadence immediately recognizes itself in the barbaric, the wild and the primitive. We observe the anarchistic intention of blowing up the continuum of history... Modernity revolts against the normalizing functions of tradition; modernity lives on the experience of rebelling against all that is normative." (Habermas 5)

Habermas's contention of modernity does not just substantiate the modern as an epoch that is the arch-other of tradition. What is further suggested is an inaccurate representation of the past/ tradition that modernity accomplishes through a strategic essentialism. In Habermas's opinion, this is done with the vested intention of augmenting the 
modern as an unprecedented state of exception. The modern self-referentially claims for itself the state of an indisputable apex of progress.

This self-referential claim to progress is substantiated and often validated by the techno-industrial material climate of modernity. With the rise of scientific rationalism and the outbreak of industrial capitalism, modernity acquired a perceivable disposition. The landscape of modernity was easily recognizable and Marshall Berman describes it thus "This is a landscape of steam engines, automatic factories, railroads, vast new industrial zones; of teeming cities that have grown overnight, often with dreadful human consequences; of daily newspapers, telegraphs, telephones and other mass media, communicating on an ever wider scale; of increasingly strong national states and multinational aggregations of capital; of mass social movements fighting these modernizations from above with their own modes of modernization from below; of an ever-expanding world market embracing all, capable of the most spectacular growth, capable of appalling waste and devastation, capable of everything except solidity and stability." (Berman 19)

While the early attributes in this rather elongated description of modernity constitute its material form, the latter is suggestive of the essence. We will engage with the latter in due course as we topicalise our study in context of a non-European politico-social culture like Turkey. Let us, for the time being, concern ourselves with the material world of modernity. For this, we prefer to emphasise the phrase 'teeming cities' that essentially identify modernity as a typically urban phenomenon. Or, to be more precise and accurate, the aspect of the urban is inextricably associated with the origins of modernity.

Although cities are not essential misnomers in history, what distinguishes them in the era of the modern is their urban disposition. The condition of urbanity is often considered as a typical phenomenon of nineteenth century when the agrarian modes of production underwent a substantial transition into industrial, leading to a demographic shift towards the 
metropolitan from the countryside. Kingsley Davis opines that the emergence of a "revolutionary new form of production - the factory run by machinery and fossil fuel" (Davis 433) led to a "transformation" that can be regarded as "the true urban revolution, for it meant not only the rise of a few scattered towns and cities but the appearance of a genuine urbanization, in the sense that a substantial portion of the population now lived in towns and cities." (ibid.) Davis identifies urbanisation as "a product of basic economic and technological developments" (ibid. 429) and the nineteenth century as the epoch of "urban revolution" (ibid. 433). The condition of urbanity thus becomes synonymous with the politico- social and cultural climate of the nineteenth century and the same is often presumed to be the age of metropolitan urbanity, i.e., the age of cities.

In his Introduction to the The Flaneur, a seminal anthology which interrogates this predominant literary-cultural archetype in varied contexts, Keith Tester observes "Flanerie, the activity of strolling and looking which is carried out by the flaneur, is a recurring motif in the literature, sociology and the art of urban, and most especially of the metropolitan, existence." (Tester 1) Hence, the urban condition is a predisposition to the flaneur and in his seminal essay "The Painter of Modern Life" Charles Pierre Baudelaire describes him as a "man of the crowd."(Baudelaire 13) The crowd for Baudelaire is not just a demographic entity. Instead the dissoluting multitude and the "ebb and the flow" (ibid. 15) is only the materialised enactment of the innate discontinuity and the fluidity that one identifies as modernity. To be modern is to be at home in this high flux of the urban which Baudelaire describes as the "enormous reservoir of electricity". (ibid.) Being at home in this changing discontinuous of modernity involves a possible reclamation of an element of essence from the fluctuating. For Baudelaire "the transient, the fleeting and the contingent" (ibid. 18) constitute the immanence of the modern. Nevertheless, the experience of the modern is not essentially limited to the fragmented discontinuous and is not devoid of any intimations of the 
transcendence. There is an-other half truth that constitutes the hemisphere of modernity. Baudelaire's painter of modern life, whom later scholars have identified as the flaneur (not without nuances though, for instance Michel Foucault refutes the strategic coherence/correspondence between flaneur and the painter of modern life. Foucault thinks the two to be distinct and differs from the canonical readings of Baudelaire by thinkers like Walter Benjamin), is in quest of this other half- that excess which lingers beneath the immanent material order of modernity. Impregnated with an urge for the excess, the flaneur attempts "to distil the eternal from the transitory." (ibid. 17-18)

Baudelaire's further ponderings on the flaneur (a substantial evaluation of it is beyond the scope of the present paper) locate him as a hyphen subject who is the embodiment of transition. In his home in the crowd, in his perennial pursuit of the significance that is contained in the insignificances of the everyday (one can refer to Michel de Certeau's Practice in Everyday Life) and above all, in his preoccupation with an excess that exceeds the nominal enterprises of the material-familial, the flaneur earns for himself the status of liminality. In the words of Walter Benjamin, the sense of being "out of place" (Benjamin 188 ) is fundamental to flanerie. What is paradoxical is the suggestion that the flaneur is at home in this essential state of out of place. His "composure" (ibid) rests in the state of being unhomed where he is exposed to the precarious state of placelessness. Referring to Allen Poe's short story which is also referred by Baudelaire, Benjamin sets up an essential distinction between the man of the crowd and the flaneur in his revisionist ponderings on the flaneur and flanerie.

"Baudelaire was moved to equate the man of the crowd, whom Poe's narrator follows throughout the length and breadth of nocturnal London with the flaneur. It is hard to accept this view. The man of the crowd is no flaneur. In him composure has given way to manic 
behavior. He exemplifies, rather what had to become of the flaneur after the latter was deprived of the milieu to which he belonged." (Ibid)

In contrast with the maniac who lacks composure, Benjamin sets up the flaneur who "demanded elbow room and was unwilling to forgo the life of a gentleman of leisure." (ibid) Benjamin observes that the "man of leisure can indulge in the perambulations of the flaneur only if as such he is already out of place." (ibid) The flaneur, for Benjamin, acquires his 'composure' in his place of 'placelessness'.

Modernity and its impersonation (the flaneur) are hence both characteristic of a precarity that is marked by nuance, paradox and ambiguity. What is characteristically modern is not appropriable through easy decipherments. Instead, they are marked by a characteristic spin on the head, a self-contrast that is never in adherence with the quintessential narrative of progress. The grand narrative of progress and the material manifestation of the technocratic that is often mistaken as not a predicament but as modernity, i.e. the essence of modernity, is suggestive of a critical myopia. An understanding of modernity demands an epistemic or critical endeavour to look beyond the matter/ form of modernity into the essence. Only then the liminal finesse of modernity is unveiled which reveals the modern condition as the state of perpetual statelessness.

The march of material modernity into the politico-social-cultural climate of the third world, which has recently been re-categorised as the Global South, is marked by a characteristic glitch. The advent of modernity in non-Europe is intimately tied to the more pertinent and historic socio-political considerations like imperialism, colonialism, secular Nationalism, political sovereignty, among others. Hence, the precarious hyphenation which marks the essence of modernity is only intensified when one takes into consideration the history of modernity in the non-European Orient. Partho Chatterjee, in his discussion on the nature of modernity in the context of a non-European culture, observes "that there cannot be 
just one modernity irrespective of geography, time, environment or social conditions...true modernity consists in determining the particular forms of modernity that are suitable in particular circumstances; that is, applying the methods of reason to identify or invent specific technologies of modernity that are appropriate for our purposes...by teaching us to employ the methods of reason." (Chatterjee 8-9) Such a topical modernity is characteristic of a hybridity where the strains of a global modern epoch is infused with more indigenous elements of culture.

This infusion is often marked by a tension and the co-existence of the global and the local is not often a happy co-habitation. This is specifically foreseen in the conflict between scientific rationalism and faith, progress and tradition and secularism and religion, industrial technocratization and the agrarian modes of production. Turkey, geo-politically located in the hyphen between West and the East, is not unfamiliar to this perpetual tension that characterises the milieu of modernity in the non-West. Alev Cinar ponders upon this climate of conflict as she observes

"...modernity is made possible by the defamation of the present. Suddenly diverse practices, customs, values, styles, and forms that have been in practice at their own pace are framed, labeled, and defamed as backward, traditional, inefficient, irrational, primitive, or corrupt and decomposed, against which the ideals of modernity can be articulated and the modern-subject can be oriented." (Cinar 23)

Cinar's notion of the present is not suggestive of a mere temporality. Instead, the present is a signifier of the elemental everyday which is profoundly absorbed in tradition, that which constitutes the intimate historicality of the self. Hence, the experience of Turkish modernity involves a constant effacement of the past and all that constitutes the discursive contingencies of the face of tradition. To be a Turk, as Soner Cagaptay observes, "can be a puzzling phenomenon" (Cagaptay 1) where irreducible considerations of tradition (in form of 
ethnic and religious practices) constantly intervene into the State advocacies of a secular model of identity. The 'Turkish' essence, in the milieu of modernity, is hence constantly interspersed by the perpetual tension between tradition and the unfamiliar, nativism and novelty, faith and reason.

Orhan Pamuk, the Nobel laureate of 2006 and the celebrated Turkish author, explores this problematic disposition of Turkish modernity in his seminal literary endeavors. His engagement with these subtlet nuances that constitute Turkish modernity and identity is explicit in his ficto-critical memoir Istanbul where the cultural paradoxes and the liminal counters of exchange where modernity and heritage co-habit are explored in the authorial reminiscences of his growth with-in the city. Simultaneously, the memoir is also suggestive of his life-long engagement with Istanbul, his city of birth and childhood which he carries in his closet of thought and consciousness. In his memoir, Pamuk writes

“Conrad, Nobokov, Naipaul—-these are writers known for having managed to migrate between languages, cultures, countries, continents, even civilisations. Their imaginations were fed by exile, a nourishment drawn not through roots but through rootlessness; mine, however, requires that I stay in the same city, on the same street, in the same house, gazing at the same view. Istanbul's fate is my fate: I am attached to the city because it has made me who I am.” (Pamuk 2006: 6)

As such, Pamuk finds home (for his childhood is inseparably attached with the everyday atmospherics of Istanbul) in the various heterogeneous elements and aspects that constitute the citysphere and include the "evenings when the sun sets early...the empty boathouses of the old Bosphorus villas...the crowds of men fishing from the sides of the Galata bridge...the beggars who accost you in the least likely places and those who stand in the same spot uttering the same appeal every day...the crowds of men smoking cigarettes after the national football matches..." (ibid. 87-89) What is suggested in this vivid and 
detailed description of the Turkish everyday is a flaneur like gaze which unfurls the urban sphere in its totality. Hence, the very praxis turned poesis of flanerie is not alien to Pamuk's pragmatics of literary representation. Instead, it is very much a constituent of his aesthetic indulgences and is often elementary to his fictional ponderings.

The present chapter locates the trope of flanerie in Pamuk's seminal novel $A$ Strangeness in My Mind. Published in 2014, the novel deals with the "Adventures and Dreams of Mevlut Karatas" and simultaneously portrays 'Life in Istanbul...from Many Different Points of View.' Mevlut in the novel is a boza seller who wanders around the nocturnal climate of Istanbul ferrying boza. Hence, flanerie is inseparable from Mevlut's performance of being. Yet, as the paper argues, flanerie in the novel is not just restrained to performativity. It is not merely in the long nightwalks that Mevlut engages in through the cityscape which substantiates him as the flaneur. Instead, for Mevlut, it is also suggested in the more elementary considerations of the ontological, that which is suggestive of a Heideggerian Dasein. Heidegger's engagement with the question of Being (Dasein) locates it outside the limits of "comport" (Heidegger 33) and conduct. For Heidegger, being is associated/ affiliated to more pre-existential questions which are "pre-ontological" (ibid. 32). The dasein is not merely the performance; it is also the essence which precedes performance. For Heidegger, "Being lies in the fact that something is, and in its Being as it is; in Reality; in presence-at-hand; in subsistence; in validity, in Dasein; in the 'there is'.” (ibid. 26)

Mevlut's lack of a consolidated claim to agency and consciousness and his discontinuous state of being exhibits a resemblance with the flaneur. The flaneur, as we have observed, is significantly characterised by the possibility of being in the liminal and the discontinuous and thus the contingent. Kieth Tester observes that "the figure of the flaneur" is characterised by its essential obsession with the "flux of life". (Tester 8) The flux, thus 
conceptualised, is the spirit of modernity and it is in perfect resonance with the spirit of flanerie. Tester observes

"Flanerie can be understood as the observation of the fleeting and the transitory which is the other half of modernity to the permanent and central sense of the self. Flanerie is the doing through and thanks to which the flaneur hopes and believes he will be able to find the truth of his being. Flanerie also, then, is the way of avoiding arrival at the funeral pyre of being." (Ibid. 7)

The avoidance of the 'funeral pyre of being' is significantly cultivated in the character of Mevlut, who constantly drifts across a facade of identities, engaging in a discontinuous state of being that is subjected to peripeteiac shifts. The very opening lines of the novel summarise this fluidity as the narrator states

"This is the story of the life and daydreams of Mevlut Karatas, a seller of boza and yoghurt... When he was twenty-five, he returned to the province of his birth, where he eloped with a village girl, a rather strange affair that determined the rest of his days: returning with her to Istanbul, he got married and had two daughters; he took a number of jobs without pause, selling his yoghurt, ice cream, and rice in the street and waiting tables. But every evening, without fail, he would wander the streets of Istanbul, selling boza and dreaming strange dreams." (Pamuk 2015: 3)

In an interview organized by Politics and Prose, Orhan Pamuk reflected that he had originally conceptualized the novel as a short story based on the simple plot of a street vendor losing his job because of modernisation but later on decided to write an epic about a man who had covered this whole distance. The referred distance, in all probabilities, is a reference to the trajectory of modernity. The boza seller, as Pamuk remonstrates, was "mysterious...a poor man who had just come from rural Anatolia, selling things to secular upper middle class Istanbullus." (Politics and Prose) Premised and habiting the overlap of the modern and non- 
modern and hence two historical timelines the boza seller becomes the perfect face of the other of modernity, or 'other modernities'. His being is conceptually premised within a liminal order of discontinuity, he is 'neither and both' here and there. Much like the flaneur, he belongs in the perpetual verge of unbelonging.

Mevlut's perennial occupation as the boza seller marks him as an irreducibly limial agency who inhabits the hyphen between tradition and modernity. For the increasingly urbanizing world of Istanbul, the boza seller is an embodiment of "centuries past, and the good old days that have come and gone.” (Pamuk 2015: 18) Mevlut's performance of boza selling in the streets of Istanbul signifies him in the popular imaginary as "a living relic of the past that had now fallen out of fashion." (ibid. 23) This 'out of place'ness is a significant trait of flanerie.

Yet, to be out of place in an ever-growing milieu of modernity is suggestive of an anachronism which is not coherent with the archetype of the flaneur. Retrospections on the flaneur and flanerie begin with a pre-consideration that emphasise the flaneur as a typical subject of urban modernity. Modernity for the flaneur is not suggestive of a dystopia. On the contrary, the flaneur is typically enticed by the provocations of modernity. The suggestion that Mevlut as the boza seller is increasingly alienated by the advent of industrial modernism (hence the feeling of out of place) derides the present objective of substantiating him as the flaneur. What is rather suggested in Mevlut's out of placeness is his status of an impoverished subject who has lost his tread to fortune due to the impediment of modernity. In a dialogue with one of those families that would often make him feel "poor and out of place" (ibid.) and that asks if he is rich, Mevlut remarks:

““'I cannot say that I am...All the relatives that came with me from the village are rich now, but I guess it just wasn't meant to be for me."”' (Ibid. 24) 
Hence, to locate Mevlut as the flaneur demands a deeper consideration of his engagement with modernity. To assume that his status of being out of place in the milieu of modernity substantiates him as the flaneur is suggestive of a critical myopia that refuses to take into consideration Mevlut's material reality of impoverishment.

Hence, to comprehend the traits of flanerie in Mevlut, it is indispensible to take into consideration his engagement with modernity. It is significant that the plot progression in the novel never happens in distinction from the progress of modernity. The novel charts the growth of Mevlut and, in doing so, takes into consideration the trajectory of modernity in Turkey. Mevlut grows in the climate of material modernity and like the representative modern subject, Mevlut depicts an unkempt desire for sovereignty. He is rather critical and subversive of the rigours and regulations of tradition and the institutional regimes of social governance. Here is an excerpt from the novel which that describes the fantasy turned desire quotient of an adolescent Mevlut.

“...he was twenty-one years old and he had never slept with a woman. A pretty girl with a headscarf and good morals, the kind he would like for a wife, would never sleep with him before they got married...His priority wasn't marriage anyway, but finding a kind woman he could hold and kiss, a woman he could have sex with. In his mind, he saw all these things as being separate from marriage, but apart from marriage, he found himself unable to obtain sexual contact." (Ibid. 152)

Mevlut's 'priority' is not marriage, the institution that guides desire within a traditional patriarchal structure. Instead, he is driven towards the urge to indulge that which constitutes the primordial. Such an indulgence foregrounds an agency which is deeply sovereign and is simultaneously transgressive towards tradition. It is in this desire to transgress the regulative that Mevlut becomes an embodiment of the essence of modernity. He is striving for modernity in spirit. 
While the spirit of transgression finds materialisation in Mevlut's decision to marry without the consent of the Father (the impersonation of tradition), the event of marriage arrives as an estrangement. The much desired elopement that is the climactic culmination of Mevlut's urge to transgress, subjects him to a momentary dystopia. As Mevlut shuts the door of the van where now sits his desired love Rayiha, he realises that the girl with whom he had fallen in love is not the one who has eloped with him. As is soon revealed, Mevlut has been subjected to a terrible deceit. While all this while he has desired Rayiha and promised her his love in carefully performed letters, while all this while Mevlut has dreamt of a life of ecstasy and contentment in the arms of his beloved, while all this while Mevlut has been haunted by those pair of eyes which he had seen in the marriage of his cousin Korkut (which he had attended against the will of the Father and thus 'tradition'), he is now estranged to realise that Rayiha is not the woman who had set flames to his heart. Instead, those pair of eyes belonged to Rayiha's sister Samiha and the Rayiha that Mevlut had conceptualised in his indulgences and performances of love is not the Rayiha who is now an inhabitant of the world. Between the conceived and the material has fallen an unerasable shadow.

To live in this shadow between the promised and the materialised is the precarious fate of the non-Western man inhabiting the milieu of modernity. For him, the arrival of modernity is a promise of novelty. In it lies the promise of change which can essentially open the doors of the stagnated politico-cultural to a radical appeal of progress. However, once arrived, the modern bears an unfamiliar disposition, often bearing a stark contrast with the intimate everyday and the familiar. The response to modernity thus appears binary patterned. One can either reject the unfamiliar and live in tradition or else recognise the unfamiliar as a unanimous truth and engage in mechanised revelry of the alien as the lived.

Mevlut in the novel chooses neither but curiously inhabits the ecstasy of the estranged. While at the realm of the personal he refabricates his desire and rekindles his love 
with Rayiha, at the more manifested realm of the modern, he chooses to be the liminal subject who has internalised the discontinuum of modernity. The estrangement of modernity does not necessarily lead him to an absolute rejection of modernity and an unconditional obsession with the non-modern inertia of tradition. Simultaneously, Mevlut is not completely obsessed with the materiality of novelty that modernisation seems to advocate. In his walks through the cityscape, Mevlut realises that "old things" (ibid. 391) made him "feel good". (ibid.) Mevlut thus occupies a curiously singular and sovereign position in his engagement with modernity. He is in pace with the flux of the modern. Yet, he is not completely absorbed by it. Hence, like the Baudelairean flaneur, Mevlut is able to look beyond the nominal and the materiality of the apparent for a deeper truth. The city for him emerges as a system of sign s that hold a secretive index to an alternative truth, that which is revealed only in a state of hyphenation and estrangement. Mevlut has internalised modernity, but not as a grand ideologue of progress. Instead, it is an internalisation that is able to decipher the essence of flux and respond to the discontinuous and the evolving. This internalisation does not necessarily suggest that Mevlut is an empty subject without a residual sense of agency. Instead, he is profoundly appealed by memory that sustains as the underlayered essence that is eternal and sovereign from the flux of change. Simultaneously, however, he is not contained within the familiar solace of past, memory and tradition. Instead, he curiously infuses the new and the old, the discontinuous and the underlying continuous and it is thus that he claims for himself the status of the flaneur who is the subject in transition without determination. 


\section{Works Cited}

Baudelaire, Charles. The Painter of Modern Life. trans. P.E. Charvet. London: Penguin Books, 2010.

Benjamin, Walter. "On Some Motifs in Baudelaire”. trans Harry Zohn. The Writer of Modern Life: Essays on Charles Baudelaire. Ed. Michael W. Jennings. Cambridge: The Belknap Press of Harvard University Press, 2006. 170-212.

Berman, Marshall. All That is Solid Melts Into Air: The Experience of Modernity. New York: Penguin Books, 1988.

Cagaptay, Soner. Islam, Secularism, and Nationalism in Modern Turkey: Who is a Turk?. London: Routledge, 2006.

Chatterjee, Partha. "Our Modernity". SEPHIS/ CODESRIA Lectures. SEPHIS \& CODESRIA, 1997.

Cinar, Alev. Modernity, Islam and Secularism in Turkey: Bodies, Places, and Time. Minneapolis: University of Minnesota Press, 2005.

Davis, Kingsley. "The Origin and Growth of Urbanization in the World". American Journal of Psychology vol. 60, no. 05, March 1955. pp. 429-437.

Habermas, Jurgen. "Modernity- An Incomplete Project." trans. Seyla Ben-Habib. The AntiAesthetic: Essays on Postmodern Culture, edited by Hal Foster. Washington: Bay Press, 1983. 3-15

Heidegger, Martin. Being and Time. trans. John Macquarrie \& Edward Robinson. Oxford: Basil Blackwell Publishers, 1962.

Pamuk, Orhan. Istanbul: Memories and the City. trans. Maureen Freely. London: Faber and Faber, 2006.

... A Strangeness In My Mind. trans. Ekin Oklap. Haryana: Hamish Hamilton, 2015. 
Politics and Prose. "Orhan Pamuk, "A Strangeness in My Mind"'”. Online Video Clip. YouTube. 19 November, 2015. Web. Accessed on $23^{\text {rd }}$ March, 2019

Tester, Keith. “Introduction”. The Flaneur. ed. Keith Tester. London: Routledge, 2015. 1-21 